\title{
METHODOLOGICAL APPARATUS FOR MONITORING MOVING OBJECTS AT THE STATE BORDER BY A RADAR STATION
}

\section{Yuliia Babii}

\section{INTRODUCTION}

According to the Law of Ukraine «On national security of Ukraine», the State Border Guard Service of Ukraine is a part of the military organization of the state, which according to its mandated functions counteracts real and potential threats to national security of Ukraine on the state border. The existing bifurcation of threats to the national security of the state, which is also implemented in the border guard sphere, reveals the need to improve the forms and methods of operational activity, weapons and military equipment, including the expansion of the functional capabilities of technical means of border protection.

The State target law enforcement program «Arrangement and reconstruction of the state border» for the period till 2020, concept documents for the development of engineering-technical equipment of the state border, which were adopted in 2015-2016 specify equipment of the border guard units with modern weapons and military equipment, which should ensure adequate monitoring of mobile objects at the state border of Ukraine. At the same time, the implementation of these and other programs reveal the need for a scientific research for conceptual approaches to monitoring, the formation of general requirements for technical means of border protection, improving the efficiency of recognition of moving objects on the state border of Ukraine.

Long-term underfunding of engineering and technical support, nonalternative use of various funds received for material and technical assistance-significantly slowed down scientific research on the choice of promising technical means of protection, justification of requirements for them. This led, in fact, to the uncertainty of the general vision in the equipment of the border.

This requires the development of a methodological apparatus in the theory of radar as a theoretical basis for the justification of effective monitoring of mobile objects on the state border in order, first of all, to automatically recognize the offender.

The task of monitoring mobile objects on the land border of Ukraine is to identify and recognize the offender against the background of interfering factors. The arrival of new radar samples requires further research in the 
selected area. Therefore, the choice of the observation position, the location of radar stations is important to ensure the continuity of observation in space and time, which requires an assessment of the impact of various factors on the range of their detection, which is an integral part of the surveillance system on the river and land areas of the border.

These information processes are hierarchical in terms of the sequence of their execution. The results of the analysis of information processing methods used in border protection radar stations allow us to note the lack of efficiency of primary processing of radar information, the lack of use of secondary and tertiary processing, which are quite complex processes in algorithmization. That is why it seems appropriate, first of all, to develop methods of secondary processing of radar information and, in the future, primary, which will increase the effectiveness of radar monitoring of mobile objects on the land border of Ukraine.

The main indicators that make it possible to distinguish the offender against the background of interference during primary processing are the effective reflecting surface, the speed and direction of movement of mobile objects relative to radar stations. These indicators are informative for radar stations of various purposes. The peculiarity of the evaluation of the effective reflecting surface and the speed of movement of mobile objects by the radar station is that the range of variation of these parameters largely overlaps for the offender and interference from large domestic and wild animals and from vegetation fluctuations. Therefore, the initial indicators of primary processing - the coordinates of the mobile object and the time of their receipt can relate to the offender, and to the interference.

\section{Analysis of the latest research and publications that initiated the solution of this problem and on which the author relies}

The main indicators that allow to recognize the offender against the background of interference during primary processing is the effective reflecting surface, the speed and direction of movement of the mobile object relative to the radar station. These indicators are informative for radar stations of various purposes.

The peculiarity of the evaluation of the effective reflecting surface and the speed of movement of mobile objects by the radar station is that the range of variation of these parameters largely overlaps for the offender and interference from large domestic and wild animals and from vegetation fluctuations.

Therefore, the initial indicators of primary processing - the coordinates of the mobile object and the time of their receipt can relate to the offender, and to the interference. 
In operating radar stations, the recognition of humans and animals is carried out by the energy method, provided that the Doppler shift of the signal frequency lies in a certain range, and the duration of its influence is not less than the specified value. Thus, the principle of operation of radar stations is based on the registration by the receiver of changes in the «interference pattern» of the electromagnetic field of a moving object in the detection zone.

When making a decision about the presence of an offender, an algorithm is used for the sequential evaluation of three features, namely:

- the frequency of the signal depending on the radial velocity of the object (carried out by the filter);

- the duration of the signal, which depends on the time of crossing the detection zone by the object (performed by the integrator);

- the amplitude of the signal, depending on the size of the moving object.

Due to the fact that many animals for speed and size not different from that of a human, the method of deciding whether the object has the fundamental ability to distinguish between human and animal. This disadvantage is inherent in all Doppler detection tools and leads to a high level of false alarms when operating these tools in places with frequent occurrence.

Thus, the disadvantage of such signal processing is low noise immunity when an animal appears in the detection zone, if its size and speed of movement can be compared with the size and speed of human movement.

To improve the effectiveness of radar stations when animals appear in the detection zone, the study proposes to apply ${ }^{1}$ a number of distinctive features. The increase is achieved by forming a vector of features in signal processing, that have more pronounced differences between humans and animals, and the use of a decision model.

\section{Presentation of the main research material}

When an object moves in the detection zone, the signal reflected from it is modulated in all parameters due to the geometric features of the object structure and the typical method of movement for this class of objects. New informative features based on the difference between human and animal movement play a crucial role in improving noise immunity.

The model of a centimeter-range radar signal creation is based on the radar equation and the description of the Doppler effect, taking into account

\footnotetext{
${ }^{1}$ Onufriev N. V., Stepanov E. A., Rusakov V. Yu. (2017) Radio wave Doppler detector. RF patent [Radiovolnovoy doplerovsky obnaruzhitel. Patent RF]. Moscow, pp. 6-11. (in Russian)
} 
that the object of detection is a complex target and is a set of elementary reflectors (elements):

$$
E_{\partial}(t)=K_{\partial} \sum_{j} K\left(\alpha_{j}(t)\right) \cdot \frac{U_{0} \lambda}{D_{j}^{2}(t)} \cdot \cos \left(\frac{4 \pi V_{j}(t) \Delta t_{j}(t)}{\lambda}\right) \cdot \sqrt{\sigma_{j}(t)},
$$

where $E_{\partial}(t)$ is the output voltage of the phase detector, V;

$K_{\partial}$ - coefficient of proportionality depending on the characteristics of the receiver;

$K\left(\alpha_{j}(t)\right.$ - coefficient of proportionality, which depends on the angle $\alpha$ between the axis of the directivity diagram of the antenna and the direction to the j-element of the movable object;

$U_{0}$ - the level of the probing signal, $\mathrm{V}$;

$\lambda$ - the wavelength of the probing signal, $\mathrm{m}$;

$D_{j}^{2}(t)$ - the distance from the radar station to the $\mathrm{j}$-th element of the mobile object, m;

$V_{j}(t)$ - radial velocity of the j-th element of a moving object, $\mathrm{m} / \mathrm{s}$;

$\Delta t_{j}(t)$ - the time for which the wave front passes from the radar station to the $\mathrm{j}$-th element of the mobile object and back, $\mathrm{s}$;

$\sigma_{j}(t)$ - effective scattering surface of the $\mathrm{j}$-th element of a mobile object, $\left[\mathrm{m}^{2}\right]$;

- number of the moving object element.

To improve the efficiency of recognition when a disturbance appears in the detection zone, it is proposed to apply a number of distinctive features in the current research, which are estimates of specific parameters of the Doppler signal that characterize the properties of the detected mobile object:

1. Man and interference differ in the speed variation of the moving parts. Human walking is a series of rhythmic and alternating movements of the limbs and body that lead to the forward movement of the center of gravity. Since, the speed of limb movements with different speed movements of the body, and the frequency of reflected signals differ from the frequency of the main peak, which leads to the expansion of the frequency spectrum of the signal from the person.

A sign for evaluating this difference is the relative broadband spectrum of the signal, as the ratio of the frequency of the maximum spectrum of the Doppler signal to its width (broadband signal): 
The attribute is calculated according to the formula:

$$
O_{1}=\frac{f_{\text {гл.max }}}{f_{\max }-f_{\min }}
$$

where is the main maximum of the amplitude-frequency spectrum of the Doppler signal, Fig. 1;

- maximum frequency of the signal spectrum by level;

- minimum frequency of the signal spectrum by level.

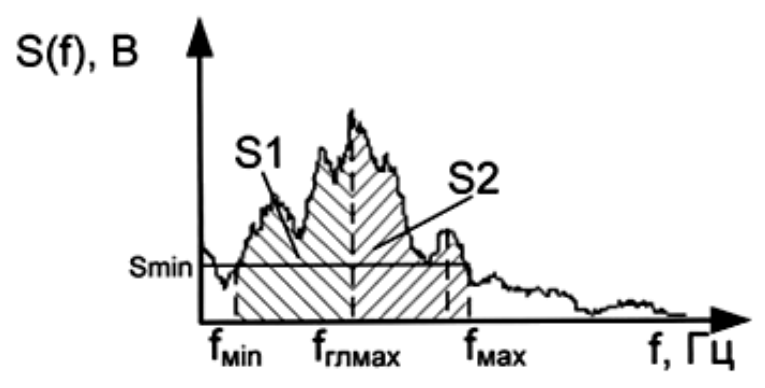

Fig. 1. Amplitude-frequency response of a moving object signal

Obviously, a person is characterized by a large broadband.

If $\mathrm{O}_{1}>0,7$, then the classifier variable $\mathrm{h}_{1}=+1$, if less, then -1 .

2. A person is distinguished by the ratio of the size of the body parts, moving at a greater and lower speed of the body. Since a person makes additional balancing movements with his hands for a uniform forward movement, therefore, in certain phases of the step, two limbs move faster than the body, and the other two limbs are slower. Since the animal does not need to make balancing movements for walking, when moving at a pace, only one limb moves faster than the trunk, and the other limbs are used as a support.

As a rule, the symmetry of the frequency spectrum of the Doppler signal is used to evaluate this difference. The attribute is calculated by the formula: 


$$
\begin{gathered}
O_{2}=\frac{\int_{\text {гл.max }}^{f_{\min }} S(f) d f}{f_{\max } S(f) d f} \\
f_{\text {гл.max }} \\
\text { where } \frac{f_{\text {гл.max }}^{f_{\min }} S(f) d f}{f_{\max } S(f) d f} \\
f_{\text {гл.max }}
\end{gathered}
$$

is the area $S_{1}$, Fig. 1, under the curve of the amplitude-frequency spectrum of the Doppler signal in the section $f_{\min }$ from $f_{\text {гл.max }}$;

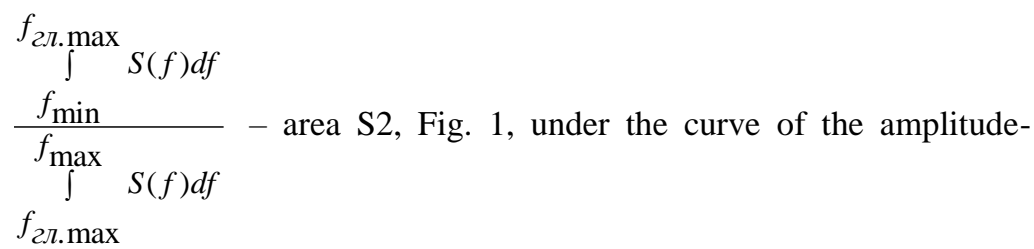
frequency spectrum of the Doppler signal in the section from to $f_{\text {гл.max }} f_{\max }$.

If $\mathrm{O}_{2}=1$, then change the classifier $\mathrm{h}_{1}=+1$, if $\mathrm{O}_{2}>1$, then $\mathrm{h}_{2}=-1$.

It should be noted that the considered features require analysis of the spectral components of the reflected signal from the moving parts of the body of a moving object. As noted $\mathrm{in}^{2}$ it is not possible to identify a particular local maximum with the signal reflected from the corresponding mobile object, since it is impossible to measure the instantaneous frequency of the signal from each mobile object and, consequently, to determine its instantaneous coordinate.

However, if we consider that each local maximum is formed as a result of the superposition of signals from the limbs of a moving object, then by summing the relative frequencies of local maxima, we can «pull out» information about the vector sum of the instantaneous dynamic coordinates of the moving object.

${ }^{2}$ Kryukov N. I. (2015) Radiolokatsionnyie sredstva ohrannogo monitoringa. Teoriya i praktika postroeniya : monografiya [Radar security monitoring equipment. Theory and practice of construction : monograph]. Moscow, 345 p. (in Russian) 
The value of the vector sum of the dynamic coordinates of the limbs of a mobile object is prone to periodic fluctuations, and the average value of these fluctuations is a constant that characterizes the movement of the mobile object.

So, to use these two features to classify a moving object is possible under the condition of a long accumulation of reflected signals from a moving object, averaging them and performing analysis.

Radar stations of optical-electronic surveillance operate in the mode of scanning a specific sector exposure of the same area a few tens of seconds, which allows us to recommend the introduction of methods of increase of efficiency of recognition of moving objects data characteristics only if the mode of target acquisition.

In the future, a weighted convolution of the surest signs (two signs) according to the classification indicator is carried out, consisting of a set of $\mathbf{j}$ (h can take the value «1» or «+1») solutions and weight coefficients $\alpha_{k}$ :

$$
M=\operatorname{sign}\left[\sum_{k}^{j} \alpha_{k} h_{k}\right]
$$

where is the result sign;

- number of solutions;

- an indicator classification.

As a result of the weighted convolution, a decision is made about the class of the detected object, namely: «plus» - the intruder, «minus» - the interference.

Improving noise immunity is achieved by making changes in signal processing - the use of recognition based on the formation of the feature vector.

To improve the efficiency of recognition when a disturbance appears in the detection zone, it is proposed to apply a number of distinctive features in the current research, which are estimates of specific parameters of the Doppler signal that characterize the properties of the detected mobile object:

- variation of speeds of moving parts of the human body and the body of an animal;

- the ratio of the size of the parts moving at a speed greater or less than the speed of the body.

It is possible to use these two features to recognize the offender among moving objects under the condition of long-term accumulation of reflected signals from moving objects, averaging them and analysis. 
Radar stations of optical-electronic surveillance operate in the mode of scanning a specific sector exposure of the same area a few tens of seconds, which allows us to recommend the introduction of methods of increase of efficiency of recognition of moving objects data characteristics only if the mode of target acquisition.

Increasing the number of recognition features will further improve the effectiveness of recognition in the mobile object of the offender. Therefore, the considered signs of primary signal processing should be supplemented with secondary processing of information, the indicators of which are specific and depend on the purpose of the radar station.

The main indicators that allow you to distinguish the offender against the background of interference during secondary processing, is the change in the coordinates of the moving object in time and space.

It is the change of coordinates, and not the coordinates themselves, significantly distinguishing the offender as a mobile object that purposefully crosses the land border.

This will allow you to recognize the offender, identify the facts of the offender's use of a known route and the emergence of new ones. It is important that the emergence of new routes can be detected in real time with the use of radar stations.

In general for secondary processing of radar information when monitoring a moving object on the land border it is necessary to process such information:

1) a priori data of coordinates of possible routes of movement of the offender in a sensitive zone of radar stations;

2) a priori data on the location of radar stations;

3) a posteriori data of primary processing of radar information about time and coordinates of the detected mobile object;

4) a posteriori data of secondary processing of radar information about the trajectory of movement of the identified offender.

The first three types of information are taken into account in the models of border security monitoring developed by Russian scientists ${ }^{3,4,5,6,7}$. In the

${ }^{3}$ Myroshnychenko V. A. (2005) Geoinformatsionnyiy metod analiza predstavleniya i territorialnoy obstanovki $\mathrm{v}$ sisteme monitoringa ohrannogo [Geoinformation method of representation and analysis of the territorial situation in the security monitoring system]. SanktPeterburh, p. 184 (in Russian)

${ }^{4}$ Ryabets Y. A. (2006) Matematiko-geoinformatsionnaya model logiko-veroyatnostnoy otsenki effektivnosti territorialno-raspredelennoy sistemyi ohrannogo monitoringa [A mathematical-geoinformation model of the logical and probabilistic evaluation of the effectiveness of a territoriallydistributed security monitoring system]. Moscow, pp. 97-106. (in Russian)

5 Babii Yu. O. (2017) Metod vtorynnoji obrobky radiolokacijnoji informaciji pry monitorynghu rukhomogho ob'jektu na sukhoputnomu kordoni Ukrajiny [The method of secondary processing of radar information during monitoring of a moving object on the land border of Ukraine]. Nauka i tekhnika povitrjanykh syl Zbrojnykh syl Ukrajiny. Kharkiv, no. 3(28). pp. 55-62. (in Ukraine) 
Ukrainian scientific works, the first type of information is taken into account in the methodology for determining the likely location of the ${ }^{8}$ offender, the basis and development of secondary processing of radar information is presented in the research ${ }^{9,10,11}$.

In the current method, it is possible to form a graph of probable routes of the offender in the controlled area. Differentiation of geo-information structure of the controlled area, subjectivity in determining the coordinates of the points through which the movement of the offender is possible indicate a very significant approximation of the true trajectories of possible routes of movement.

The emergence of a new unknown route of movement, the deviation of the trajectory of the offender from the known routes-does not allow to fully provide effective conditions for the detention of the offender using the provisions of the current methodology.

${ }^{6}$ Babii Yu. O., Lysyj M. I. (2018) Metodyka pidvyshhennja dostovirnosti rozpiznavannja pravoporushnyka pry monitorynghu rukhomogho ob'jekta radiolokacijnoju stancijeju. Pidsumky rozvytku naukovoji dumky [The technique of increasing the accuracy of the recognition of the offender when monitoring a moving object by a radar station]. Zb. nauk. pracj « $\Lambda O G h O \Sigma$ : materialy Mizhnarodnoji naukovo-praktychnoji konferenciji, Vinnycja : Vyd-vo «Jevropejsjka naukova platforma», vol. 1, pp. 14-16. (in Ukraine)

${ }^{7}$ Babii Yu. O., Lysyj M. I. (2018) Alghorytm rozpiznavannja metodyky pidvyshhennja efektyvnosti rozpiznavannja pravoporushnyka pry monitorynghu rukhomogho ob'jekta radiolokacijnoju stancijeju [Algorithm recognition algorithm for enhancing the efficiency of offender recognition when monitoring a moving object by a radar station]. Rolj innovacij $v$ transformaciji obrazu suchasnoji nauky : materialy 2-oji Mizhnar. naukovo-prakt. konf. (m. Kyjiv, 28-29 ghrudnja 2018 r.). Kyjiv : Vyd-vo In-tu innovacijnoji osvity, pp. 99-100. (in Ukraine)

${ }^{8}$ Horodnov V. P. (2008) Model vyznachennia ymovirnykh marshrutiv rukhu porushnykiv kordonu poza punktamy propusku cherez derzhavnyi kordon [A model for determining possible routes for violators crossing the border outside the border crossing points]. Khmelnytsky, pp. 11-17. (in Ukraine)

${ }^{9}$ Snitsarenko P. M. (2016) Teoriia ozbroiennia. Naukovo-tekhnichni problem ta zavdannia: monohrafiia: Tekhnichni zasoby. Viiskovi systemy dystantsiinoho monitorynhu navkolyshnoho prostoru shchodo rukhomykh obiektiv: metodolohichni aspekty obgruntuvannia vymoh [The theory of weapons. Scientific and technical problems and tasks: monograph: technical means. Military systems of remote monitoring of the surrounding space in relation to moving objects: methodological aspects of substantiation of requirements]. Kiev, 480 p. (in Ukraine)

${ }^{10}$ Hryzo A. A. (2017) Udoskonalennia vtorynnoi obrobky radiolokatsiinoi informatsii v RLS [Improvement of the secondary processing of radar information in the radar]. Kharkiv, pp. 78-81. (in Ukraine)

${ }^{11}$ Kovtunov A. L. (2013) Metodyi vtorichnoy obrabotki radiolokatsionnoy informatsii v obzornyih RLS, ispolzuyuschih polyarnuyu sistemu koordinat $\mathrm{s}$ primeneniem sverhshirokopolosnyih signalov [Methods of secondary processing of radar information in survey radars using a polar coordinate system using ultra-wideband signals]. Kharkiv, pp. 74-78. (in Ukraine) 
It is important to recognize the route of the offender on the basis of the identified features of changing the trajectory of the offender and interference, which are put in the development of a method of secondary processing of radar information when monitoring a mobile object on the land border of Ukraine.

The relevance of the development of this technique to improve the efficiency of recognition of the offender of the state border when monitoring mobile objects by radar is due to the fact that many years of experience in the operation of radar means of border protection indicates that the greatest flow of false alarms comes from the movement of animals.

Just a few of these triggers per shift, so that the outfit refused to act correctly on the alarm and disdained the technical means of protection.

The technique is designed to recognize the movement of the offender in the area of the radar station taking into account the data of the secondary processing of radar information and is based on the supplemented features of the classification of the mobile object.

The initial data for the calculations are as follows:

- time and coordinates of the detected moving object;

- a database of possible routes of movement of the offender;

The structure of the methodology has the following components:

- determination of the indicator and criterion for monotonicity of changes in at least one of the coordinates of the moving object.

- development of an algorithm for secondary processing of radar information when monitoring mobile objects on the land border.

The method is characterized by the expansion of the set of signs of recognition of the offender and a sign of purposefulness of the trajectory of the mobile object. This allowed, according to the developed indicator and criterion of purposefulness, to recognize the offender against the background of interference, for example, the movement of animals.

Let's make an assumption:

- the offender purposefully crosses the border.

- the offender has no information about the operation of the radar station.

The first assumption is based on the very essence of illegal activity, as conscious actions in the space-time field. The basis for the second assumption is the masking effect of the radar station and the confidentiality of information.

Then, in General, the trajectory of a moving object that moves through the sensitive zone will be classified as:

- chaotic (the course of movement changes chaotically);

- purposeful (the course of movement changes in a certain direction); 
- defined (road section).

It is characteristic that for a chaotic trajectory there is a significant excess of the length of the path traversed by a mobile object from the initial and to the final point of the trajectory for the distance between them, which is a classifying feature of determining the trajectory of animals.

Let us assume that the movement of animals or the oscillation of vegetation is characterized, to a large extent, by randomness of direction, not purposefulness. Let us assume that the movement of animals or the oscillation of vegetation is characterized, to a large extent, by randomness of direction, not purposefulness. This makes it possible to form an indicator of purposefulness:

$$
M=1-\frac{L_{1 N}}{\sum_{i=1}^{N} L_{i}},
$$

where $M$ is the indicator of purposefulness of the trajectory of a moving object;

$N$ - number of the last location point of the mobile object measured by the radar station;

$L_{i}$ - the length of the trajectory section between two successively measured points of the moving object location;

$L_{1 N}$ - the length of the trajectory section between the first and last points of the moving object location.

The threshold of the decision making will be the cases when the trajectory length exceeds not more than twice the distance from the beginning of detection and to the end point of detection of the moving object of the radar station. Then the criterion for moving the offender, recognizing it against the background of interference is inequality:

$$
M \leq 0,5
$$

Advanced technique intended to detect the movement of the offender in range of a radar station and is based on augmented considered the classification of the movable object. The main stages are presented in the form of an algorithm (figure 2). The more signs of recognition of the offender's movement from the interference, the more effective the technique. 


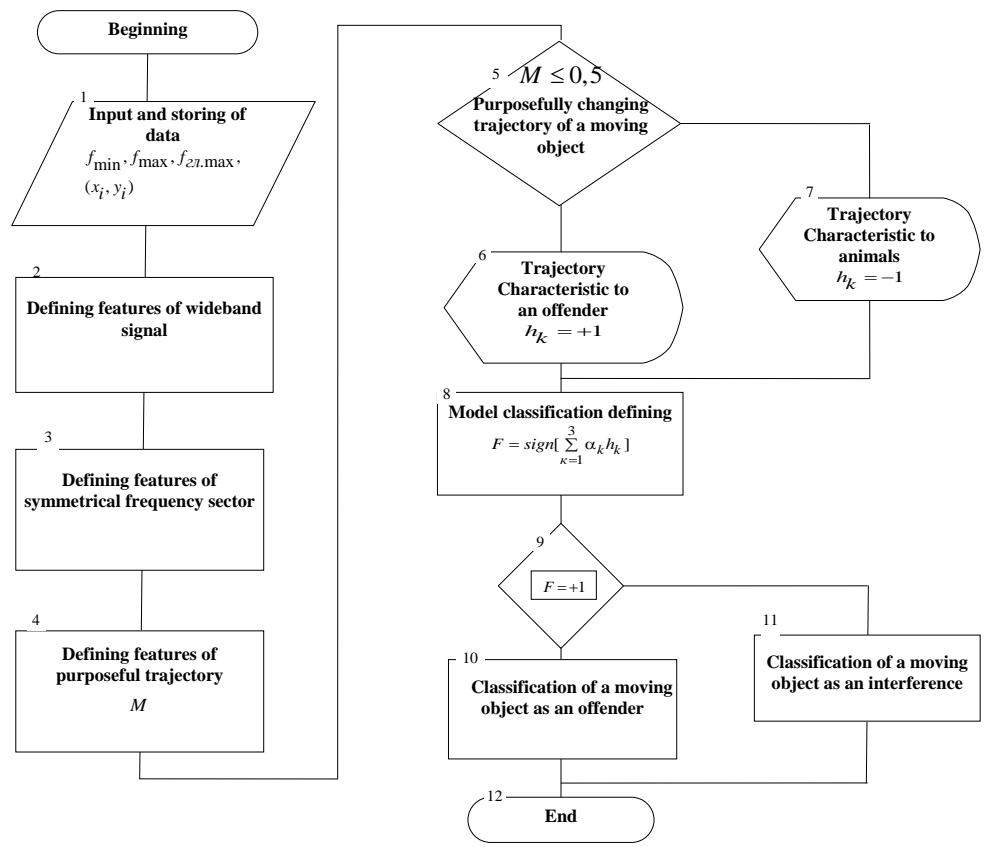

Fig. 2. Algorithm for improving the effectiveness of offender recognition when monitoring a moving object by a radar station

The first blocks of the algorithm include the use of the existing distinctive signs which may be supplemented by a new classification characteristic of the trajectory of movement of the movable object - for the targeted trajectory is substantially increased path length of a moving object from the initial to the final point of the trajectory for the distance between them, which is a classifying feature of the definition of the trajectory interference. This made it possible to recognize the offender's movements against the background of interference (figure 3). 


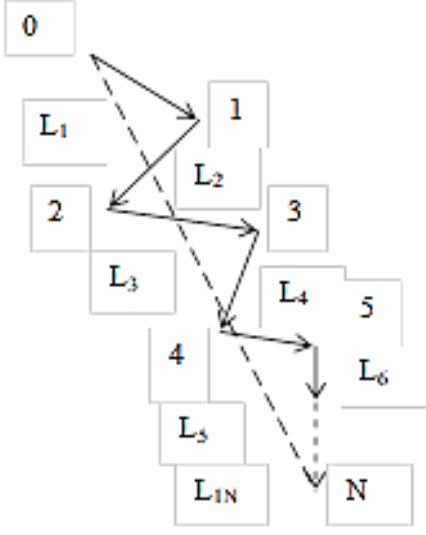

a)

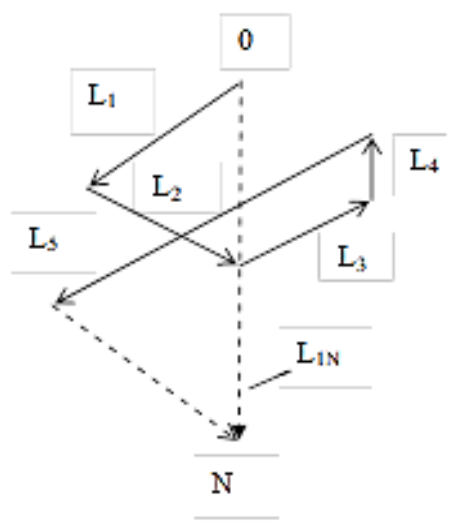

b)

\section{Fig. 3. Trajectory of a moving object: a) human; b) interference}

The developed algorithm reflects the main stages of the method and provides:

- calculation of recognition features by primary processing of the radar signal, blocks 2, 3 (expressions 2; 3);

- determination of the purposefulness of the trajectory of a mobile object according to the developed indicator and criterion for secondary information processing, blocks 4, 5;

- calculation of the indicator and criterion of recognition of the offender by the current method, blocks 8,9 (expression 4);

- issuing an alarm when an offender is detected, block 10.

The developed algorithm allows you to recognize a single offender against the background of interference from the movement of the animal.

Models and new technical solutions for tertiary information processing can be used to assess the trajectory of a group of offenders and to highlight the impact of interference.

In the algorithm of the method of increasing the efficiency of recognition of the offender when monitoring mobile objects by radar, the first three blocks are carried out according to the current method described in the work of Kryukov N. I. and provides spectral analysis of the Doppler signal reflected from various parts of the body of the mobile object. The remaining blocks describe the application of the proposed sign of purposefulness of the trajectory of a moving object. 


\section{CONCLUSIONS}

Thus, we note the following:

the set of signs of recognition of the offender by the radar station is expanded, the criterion of purposefulness is defined;

the trajectory of a movable object is classified as chaotic, purposeful and determined, in accordance with the established features of the classification:

a) if there is not a monotonous change in at least one $x_{i}, y_{i}$ coordinate of the object, which is a sign of classification of moving interference, the trajectory is referred to as chaotic or definite, the movement on it is not purposeful, in this case, basically moving object is an interference;

b) the next sign of classification is the coincidence of the trajectory of the moving object with the possible route of the offender's movement through the sensitive zone, such a trajectory is classified as defined, and the moving object is taken for the offender;

c) if the trajectory is not classified as chaotic or of a certain type, it is considered purposeful.

\section{SUMMARY}

The technique of improving the efficiency of border offender (moving object) detection during radar monitoring on the basis of secondary information processing is made in the article.

An algorithm for the method of increasing the efficiency of border offender recognition during radar monitoring has been developed, which further allowed y allowed to identify a single moving object against the background of noise.

The method of increasing the effectiveness of recognition of the offender when monitoring mobile objects by radar has been improved. The method is characterized by the expansion of the set of signs of recognition of the offender and a sign of purposefulness of the trajectory of the mobile object. This made it possible, according to the developed indicator and criterion of purposefulness of the trajectory of a mobile object, to increase the efficiency of recognition of the offender against the background of interference.

The reliability of the improved methodology was confirmed by the result of an experiment conducted in the Podolsk border detachment with the use of radar stations of the Optical-electronic observation system. The efficiency of radar recognition of the offender against the background of interference was increased by 20-24\% when referring to the trajectory of the moving object to a targeted view. 


\section{REFERENCES}

1. Onufriev N. V., Stepanov E. A., Rusakov V. Yu. (2017) Radio wave Doppler detector. RF patent [Radiovolnovoy doplerovsky obnaruzhitel. Patent RF]. Moscow, pp. 6-11. (in Russian)

2. Kryukov N. I. (2015) Radiolokatsionnyie sredstva ohrannogo monitoringa. Teoriya i praktika postroeniya. Monografiya [Radar security monitoring equipment. Theory and practice of construction. Monograph]. Moscow, 345 p. (in Russian)

3. Myroshnychenko V. A. (2005) Geoinformatsionnyiy metod analiza predstavleniya i territorialnoy obstanovki $\mathrm{v}$ sisteme monitoringa ohrannogo [Geoinformation method of representation and analysis of the territorial situation in the security monitoring system]. Sankt-Peterburh, p. 184 (in Russian)

4. Ryabets Y. A. (2006) Matematiko-geoinformatsionnaya model logiko-veroyatnostnoy otsenki effektivnosti territorialno-raspredelennoy sistemyi ohrannogo monitoringa [A mathematical-geo-information model of the logical and probabilistic evaluation of the effectiveness of a territoriallydistributed security monitoring system]. Moscow, pp. 97-106. (in Russian)

5. Babii Yu. O. (2017) Metod vtorynnoji obrobky radiolokacijnoji informaciji pry monitorynghu rukhomogho ob'jektu na sukhoputnomu kordoni Ukrajiny [The method of secondary processing of radar information during monitoring of a moving object on the land border of Ukraine]. Nauka $i$ tekhnika povitrjanykh syl Zbrojnykh syl Ukrajiny. Kharkiv, no. 3(28). pp. 55-62. (in Ukraine)

6. Babii Yu. O., Lysyj M. I. (2018) Metodyka pidvyshhennja dostovirnosti rozpiznavannja pravoporushnyka pry monitorynghu rukhomogho ob'jekta radiolokacijnoju stancijeju. Pidsumky rozvytku naukovoji dumky [The technique of increasing the accuracy of the recognition of the offender when monitoring a moving object by a radar station]. Zb. nauk. pracj " $\Lambda O G h O \Sigma »$ : materialy Mizhnarodnoji naukovopraktychnoji konferenciji, Vinnycja : Vyd-vo «Jevropejsjka naukova platforma», vol. 1, pp. 14-16. (in Ukraine)

7. Babii Yu. O., Lysyj M. I. (2018) Alghorytm rozpiznavannja metodyky pidvyshhennja efektyvnosti rozpiznavannja pravoporushnyka pry monitorynghu rukhomogho ob'jekta radiolokacijnoju stancijeju [Algorithm recognition algorithm for enhancing the efficiency of offender recognition when monitoring a moving object by a radar station]. Rolj innovacij $v$ transformaciji obrazu suchasnoji nauky : materialy 2-oji Mizhnar. naukovoprakt. konf. (m. Kyjiv, 28-29 ghrudnja 2018 r.). Kyjiv : Vyd-vo In-tu innovacijnoji osvity, pp. 99-100. (in Ukraine)

8. Horodnov V. P. (2008) Model vyznachennia ymovirnykh marshrutiv rukhu porushnykiv kordonu poza punktamy propusku cherez derzhavnyi 
kordon [A model for determining possible routes for violators crossing the border outside the border crossing points]. Khmelnytsky, pp. 11-17. (in Ukraine)

9. Snitsarenko P. M. (2016) Teoriia ozbroiennia. Naukovo-tekhnichni problem ta zavdannia: monohrafiia: Tekhnichni zasoby. Viiskovi systemy dystantsiinoho monitorynhu navkolyshnoho prostoru shchodo rukhomykh obiektiv: metodolohichni aspekty obgruntuvannia vymoh [The theory of weapons. Scientific and technical problems and tasks: monograph: technical means. Military systems of remote monitoring of the surrounding space in relation to moving objects: methodological aspects of substantiation of requirements]. Kiev, 480p. (in Ukraine)

10. Hryzo A. A. (2017) Udoskonalennia vtorynnoi obrobky radiolokatsiinoi informatsii $\mathrm{v}$ RLS [Improvement of the secondary processing of radar information in the radar]. Kharkiv, pp. 78-81. (in Ukraine)

11. Kovtunov A. L. (2013) Methods of secondary processing of radar information in survey radars using a polar coordinate system using ultrawideband signals [Metodyi vtorichnoy obrabotki radiolokatsionnoy informatsii v obzornyih RLS, ispolzuyuschih polyarnuyu sistemu koordinat $\mathrm{s}$ primeneniem sverhshirokopolosnyih signalov]. Kharkiv, pp. 74-78. (in Ukraine)

\section{Information about the author:} Yuliia Babii, Doctor of Technical Sciences, chief of doctorate, Bohdan Khmelnytsky National Academy of the State Border Guard Service of Ukraine 46 Shevchenko str., Khmelnitskyi, 29007, Ukraine ORCID ID: orcid.org/0000-0001-7310-8715 